\title{
Women with Substance Abuse Problems Exposed to Men's Violence - A Public Mental Health Challenge
}

\author{
Christina Scheffel Birath ${ }^{1,2 *}$, Ulla Beijer ${ }^{3}$, Valerie DeMarinis ${ }^{2,4}$ and Britt af Klinteberg ${ }^{3,5,6}$ \\ ${ }^{1}$ Stockholm Centre for Dependency Disorders, Stockholm, Sweden \\ ${ }^{2}$ Area of Psychology of Religion, Uppsala University, Uppsala, Sweden \\ ${ }^{3}$ Department of Women's and Children's Health, Karolinska Institute, Stockholm, Sweden \\ ${ }^{4}$ Public Mental Health and Meaning Research Area, Impact Research Programme, Uppsala University, Uppsala, Sweden \\ ${ }^{5}$ Centre for Health Equity Studies, Stockholm University/Karolinska Institute, Stockholm, Sweden \\ ${ }^{6}$ Department of Psychology, Stockholm University, Stockholm, Sweden
}

\begin{abstract}
Objective: To explore self-rated physical and psychological health in two groups of women with substance misuse problems, subjected to male violence.

Methods: An examination of the health situation for women with substance dependence being exposed to male violence during life. The study took place in a Swedish context exploring data from 35 women with housing $(\mathrm{WwH})$ and 44 homeless women (HW), regarding posttraumatic stress disorder symptoms, psychological and physical problems. Mann-Whitney U-test and Pearson's correlation coefficient were used to calculate differences between groups and correlations.
\end{abstract}

Results: The proportion of women being exposed to male violence during life for the studied group was $91 \%$ ( 72 of 79 women; WwH 29; HW 43). It was found that the WwH had physical health problems but compared to the HW, significantly less frequent. Regarding psychological health problems, both groups were suffering from self-reported problems, most notably in variables measuring stress susceptibility and embitterment, where both WwH and HW had scores markedly above norm mean scores. The HW had overall a poorer mental health profile as compared to the $\mathrm{WwH}$. The $\mathrm{WwH}$ still maintained a foundation in the society compared to the HW regarding housing $(100 / 0 \%)$, and custody over their children (91/0\%).

Conclusion: The study indicated that women with substance dependence and those who are victims of male violence have major problems with both their psychological and physical health. Particularly vulnerable are the HW. Past experiences of violence that have not been processed can further aggravate the women's health. Thus, we suggest initiating the process of asking women if they have experienced violence in order to then be able to provide appropriate treatment interventions. For the $\mathrm{WwH}$, this process may lead to a prevention of serious consequences for both their housing situation and for their health.

Keywords: Substance misuse problems; Male violence

\section{Introduction}

Alcohol and substance abuse are main public mental and physical health issues. About $4.3 \%$ of the women in Sweden over 18 years old have alcohol dependence and $10.5 \%$ suffer from alcohol abuse [1]. Additional 25,000 have drug addiction problems of which one fourth are females. Over and above well documented physical and psychological consequences of substance abuse, there is a substantial risk for substance abusers to be eliminated from the labour market, social network and family networks [2,3]. Before being socially isolated from the community most of these women and their families have suffered a lot. If no arrangements such as forms of prevention and/or treatment are made, some will lose not only work, but also home and dignity [4].

Consequences for mental and physical ill-health of substance dependence are described in a number of studies [5-7]. An increased risk of homelessness for individuals with concomitant substance abuse is documented [8,9]. In Sweden there is a large homeless population problem with between 4,500 to 11,500 homeless women, where 2,000 to 3,000 of them have a substance abuse or dependence problem $[10,11]$. Homeless women's health, physical as well as mental is poor [12,13]. Regarding mental illness there was found to be nearly triple relative risk of schizophrenia and personality disorder related to the combination of homelessness and substance abuse $[13,14]$. WwH and substance abuse or dependency problems are also a group at risk for health problems, having high frequencies of comorbidity with anxiety and mood disorders [15-17]. No study has been found discussing or comparing the vulnerability for mental and/or physical health for $\mathrm{WwH}$ and $\mathrm{HW}$ with such substance abuse problems.

Situations of violence are well-known to be far more common in environments where there are drug- and/or alcohol use. Being exposed to violence is shown to increase the vulnerability for physical and psychological illness. A wide range of symptoms originating from one or more events are presented [18]. One of the most serious psychological consequences of being exposed to stressful events is Posttraumatic Stress Disorder (PTSD) symptoms. PTSD can be characterized by hyper arousal, intrusion, emotional numbing, and avoidance, where the latter includes attempts to avoid reminders of the event(s) by using alcohol and/or drugs [19].

*Corresponding author: Christina Scheffel Birath, Stockholm Centre for Dependency Disorders, Box 17914, SE 118 95, Stockholm, Sweden, Tel: +46-70736-27-69; Fax: +46-8-123-495-14; E-mail: christina.scheffel-birath@sll.se

Received May 02, 2013; Accepted May 21, 2013; Published May 26, 2013

Citation: Birath CS, Beijer U, DeMarinis V, af Klinteberg B (2013) Women with Substance Abuse Problems Exposed to Men's Violence - A Public Mental Health Challenge. J Addict Res Ther 4: 149. doi:10.4172/2155-6105.1000149

Copyright: @ 2013 Birath CS, et al. This is an open-access article distributed unde the terms of the Creative Commons Attribution License, which permits unrestricted use, distribution, and reproduction in any medium, provided the original author and source are credited. 
Since many individuals suffering from substance dependence disorders have been raised in families with parental substance abuse problems and/or psychiatric ill-health, there is an elevated risk that they also have been exposed to violence as children. Being exposed to violence during childhood or adolescence has proved to be related to psychological health problems later in life [20]. Experiencing violence during childhood might exaggerate the development of certain vulnerability aspects of personality [21]. There are also elevated risks for physical diseases in addition to the injury inflicted by the physical abuse. Physical and mental health are closely intertwined and affect each other and, when focussing on public health promotion it is emphasized that these areas need to be studied together [2].

The cultural context in which treatment takes place affects the way environmental factors are met. In the Swedish society there is a tradition to pay attention to evidence-based treatment methods [22]. Most of them, like Motivational Interviewing (MI) [23], relapse prevention, and skills training $[24,25]$ have a strong focus on the substance abuse problems only. The need to include additional aspects has been outlined in studies, for example the importance for women in treatment for their alcohol problems to discuss gender aspects, violence, and their children's situation [26,27].

To pay attention not only to the substance abuse problem but also to including environmental factors early in the treatment process could limit the consequences for the society, the individual and the risk for mental illness in the next generation [2]. Women are as likely as men to develop substance abuse problems [28], but the consequences can be different for them as compared to men [28]. They often have a greater responsibility for the family and the next generation. Therefore, women may be an important target for interventions. Important from this base of knowledge are prevention and treatment options. There is an urgency to begin to identify, as early as possible, high-risk individuals regarding exclusion from labour market, social networking, and housing [2].

In the light of these findings, through a framework of interactionoriented theory, we aimed at exploring self-rated physical and psychological health in women with housing $(\mathrm{WwH})$ and homeless women (HW), both groups subjected to male violence. From a public health aspect, in this study we hypothesized that the HW as compared to the $\mathrm{WwH}$ would display more severe self-rated health problems.

\section{Methods}

\section{Study sample}

Between March 2009 and April 2010, 79 women with substance misuse in Stockholm were interviewed; 35 women with housing $(\mathrm{WwH})$ participating in outpatient treatment for substance misuse, and 44 homeless women (HW) with or without treatment for substance misuse in contact with Social Services. When in contact with Social Services, there is a standing offer to participate in treatment for substance abuse problems, though not mandatory for receiving help. Women were asked to participate in the study by the staff at the respective units or by a researcher when visiting each participant unit.

HW in the present study were individuals without a residence, owned or rented, had no permanent address, had to rely on temporary housing options, or were living rough. Women in shelters or temporarily living in institutions were also included.

There were some missing data on items randomly distributed over the measurements for one of the subjects included in the HW group.

\section{Drop-out analysis}

A sample of 143 woman was asked to participate in the study: 74 $\mathrm{HW}$ and $69 \mathrm{WwH}$. Of these, $9 \mathrm{HW}$ agreed to participate but failed to come to the interview, $10 \mathrm{HW}$ got the questionnaire through a social welfare secretary, staff at temporary living institutions, or by telephone (answering machine) but did not give any answer, and 45 women (34 $\mathrm{WwH}$ and $11 \mathrm{HW}$ ) refused to participate (Figure 1). Of the $30 \mathrm{HW}$ who did not participate in the study, the age was known for 27 of them, with an average age of 43.5 ( $\mathrm{SD}=7$, range: $32-58$ ) years. As far as it was possible to clarify, $\mathrm{WwH}$ and $\mathrm{HW}$ who did not participate in the study were similar to those who participated as no conclusive differences were obtained. We therefore concluded that the $\mathrm{WwH}$ and $\mathrm{HW}$ may be considered representative of the population of $\mathrm{WwH}$ and $\mathrm{HW}$ in Stockholm. In comparison, the population of HW with substance misuse in Stockholm 2000-2002 had an average age of 39 (SD=11, range 18-65) years. Half of the HW in total in Stockholm's City 2001, with or without substance misuse, had psychological problems, and about $60 \%$ of the HW with misuse problems used illicit drugs as the dominating preparation [29]. Women in treatment that refused participation in this study had an average age of 46.7 ( $S D=9$, range: $28-70)$ years. A cohort of 134 women, that between 2001 and 2005 voluntarily sought treatment for their alcohol problems at the unit, were studied, and had an average age of 42 ( $\mathrm{SD}=7$, range 22-58) years [15]. Women with substance misuse in Stockholm City 2000-2002 had an average age of $41(\mathrm{SD}=11$, rang 18-65) years.

Exclusion criteria were: language-related problems, problems of understanding the questions in the survey, and if the women had such serious and acute psychiatric diseases that participation was considered as an increase in her suffering.

\section{Ethical permission}

The participants gave informed written consent to participate in the study, and had the opportunity to withdraw at any point. They also were informed that their participation was voluntary and their treatment/management at the unit would not be affected whether they participated or not. The study was approved by the Stockholm Regional Ethics Committee (Dnr 2009/2144-31/5).

\section{Measurement}

IES-R, Impact of Event Scale-Revised [19], a scale containing 22 items about degree of distress during the past week related to a specific upsetting event in the past, $(0=$ not at all to $4=$ very much) full scale score 88 and three subscales which reflect intrusion (eight items about thinking and feeling about the incidence that disturbs the daily

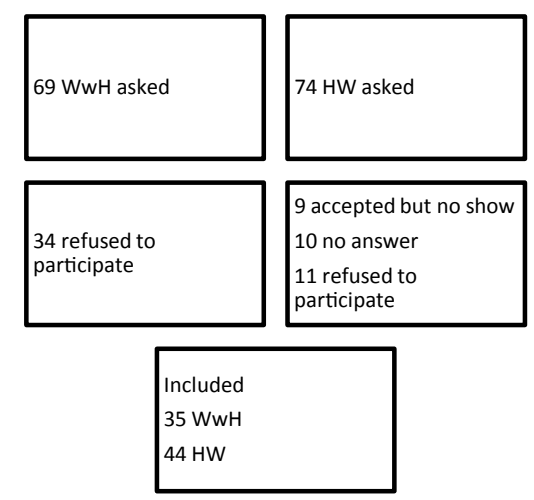

Figure 1: Inclusion process in the study for $\mathrm{WWH}$ and $\mathrm{HW}$. 
life), avoidance (eight items about intentional avoiding situations or thoughts reminding about the incidence), and hyperarousal (six items about problems with physical or psychological calmness related to the incidence). The IES-R score does not provide a PTSD diagnosis though mean subscale score higher than 1.5 on each subscale or a full scale score of 33 indicate Post Traumatic Syndrome (PTSD) symptoms $[30,31]$.

Swedish Universities Scales of Personality (SPSS) [32], a revised and reduced version of the KSP measuring personality traits with 91 multiple-choice questions, giving different aspects of the personality in 13 different scales (Cronbach's alpha coefficients ranged from 0.59 to 0.84 ) [32]: somatic trait anxiety, psychic trait anxiety, stress susceptibility, lack of assertiveness, impulsiveness, adventure seeking, detachment, social desirability (reversed scale), embitterment, trait irritability, mistrust, verbal trait aggression, physical trait aggression. An example of a statement in the questionnaire is: "I easily start to argue with others if they express another opinion." Each statement in the questionnaire has four response alternatives: It is exactly right; it is fairly right; it is fairly wrong; it is not right at all. Through factor analysis a three-factor solution corresponding to personality theories is used: neuroticism, aggressiveness and extraversion.

A shortened version of the World Health Organization questionnaire [33] of male violence against women - experience of men's physical and , psychological violence, sexual abuse, number and incidence of assault, and domestic violence between the adults during childhood was completed by the subjects. Questionnaires concerning relation to male perpetrator(s) (partner, father, acquaintance, etc.), if the violence was reported to the police, if the report passed to perpetrator(s), any help they got and from whom, and experienced satisfaction with this help/support, were formulated for this study by the authors.

ASI, Addiction Severity Index [34,35], was used for information about substance misuse problems, physical and psychological health, family situation, marital status, children, experience of the justice system.

\section{Data analyses}

Descriptive statistics were calculated and inter-correlations between variables performed using Pearson's correlations. Imputation of missing items in SSP and IES-R were imputed with the mean of completed items if $\geq 5$ out of 7 items of the scale respectively were answered. To explore differences between groups in SSP, IES-R and ASI scales, Mann-Whitney U-tests were applied. Statistical analyses for data were performed in Statistical Package for the Social Sciences SPSS (version 18.0).

\section{Results}

\section{Demographic information}

Included in the study were 79 women, $35 \mathrm{WwH}$ and $44 \mathrm{HW}$. The mean age of the 79 women was 47.6; WwH 48.3; HW 47.0 years ( $\mathrm{SD}=10.0 ; 10.2 ; 9.9$, range, 21-68). Most were of Swedish nationality (94\%), and the remaining came from other European countries, mainly from the Nordic countries. Of the $44 \mathrm{HW}$ more than half of them had been homeless for 10 years or longer, $28 \%$ for five to nine years, and $14 \%$ for four or less. The $35 \mathrm{WwH}$ have been living at the same place in mean 3.6 years. About half of them completed a college education. Eighteen percent failed to complete grammar school. The educational level for the $\mathrm{WwH}$ was higher, less than $10 \%$ failed to complete grammar school; about half of the group had completed a college education. Most of the women had children (78.5\%) and their mean age was 20 years old (range 0-46). The WwH had custody of 30 of in total 33 (91\%) children under 18 years, and the HW none of in total 16 children under 18 years. For more demographic information with respect to the WwH and HW exposed to male violence (Table 1).

Most of the women were using or abusing alcohol and all $\mathrm{WwH}$ had been diagnosed with alcohol dependence disorder. The mean score for the $\mathrm{WwH}$ alcohol consumption days during the last 30 days was 6.8 days ( $\mathrm{SD}=9$; range $0-30$ ). Most frequent drug use/abuse during the last 30 days was amphetamine used by 24 of the HW in mean 7.3 days $(\mathrm{SD}=12.2$; range $0-30)$. Both groups were suffering from physical illhealth as prolonged physical damage/illness (WwH 51\%; HW 82\%), receiving medication for physical problems (WwH 43\%; HW 45\%), and had Hepatitis $\mathrm{C}$ virus infection (WwH 6\%; HW 70\%).

\section{Exposed to male violence}

In total, $91 \%$ (72 of 79 women; WwH 29; HW 43) had experienced male violence. In total 99\% (WwH 97\%; HW 100\%) reported experiences of emotional/psychological violence, $90 \%$ (WwH 83\%; HW 95\%) physical, and 61\% (WwH 59\%; HW 63\%) sexual violence. Nearly two fifths (WwH 18\%; HW 82\%) of the women had been assaulted during the past year and about one-fifth (WwH 10\%; HW 33\%) from their current partner, most exposed by numbers and times were the HW. About a third of the women (WwH 34\%; HW 28\%) had been abused by the father or another male relative, for further information about the number of women in the respective group subjected to violence during childhood (Table 2).

\section{IES-R}

Results from the IES-R are presented in full scale score (max 88), and in three subscales (Intrusion, Avoidance, and Hyperarousal). The results show that 33 of the 72 exposed women experienced severe consequences from the reported event (more than 33 points). Subscale means for all women indicate that the HW scored in mean above 1.5 in all subscales, i.e. experienced problems regarding at least one of the events that suggest a PTSD diagnosis, as shown in Table 3. Results from Mann-Whitney test for independent samples show significant differences between the exposed $\mathrm{WwH}$ and the exposed $\mathrm{HW}$ regarding the IES-R full score and all subscales, indicating posttraumatic

\begin{tabular}{|c|c|c|c|c|}
\hline & WwH & HW & $\mathbf{F}$ & $p$ \\
\hline \multicolumn{5}{|c|}{ Childhood } \\
\hline Grew up with both parents to age 16 & 20 & 17 & 6.37 & 0.14 \\
\hline Domestic violence in parental home & 5 & 18 & 5.03 & 0.28 \\
\hline Seen domestic violence in parental home & 4 & 11 & 2.00 & 0.12 \\
\hline Alcohol/drug problems among parents & 15 & 34 & 9.26 & 0.003 \\
\hline Mental health problems among parents & 12 & 11 & 2.06 & 0.157 \\
\hline \multicolumn{5}{|c|}{ Present life situation } \\
\hline Single & 20 & 36 & 2.19 & 0.144 \\
\hline Having children & 27 & 29 & 4.15 & 0.046 \\
\hline \multicolumn{5}{|c|}{ Substance abuse problems } \\
\hline Alcohol/drugs before 15 y & 12 & 32 & 8.69 & 0.004 \\
\hline Abused alcohol/drugs more than $15 \mathrm{y}$ & 10 & 35 & 18.82 & 0.0001 \\
\hline Ever treatment in outpatient care & 29 & 36 & 4.70 & 0.034 \\
\hline \multicolumn{5}{|c|}{ Physical health } \\
\hline Prolonged physical illness & 15 & 36 & 11.04 & 0.001 \\
\hline Hepatitis C Virus Infection (HCV) & 2 & 31 & 30.62 & 0.0001 \\
\hline HIV & 0 & 8 & 3.50 & 0.036 \\
\hline
\end{tabular}

Table 1: Sociodemograhpic data for the $\mathrm{WwH}(n=29)$ and $\mathrm{HW}(n=43)$ being exposed to male violence 


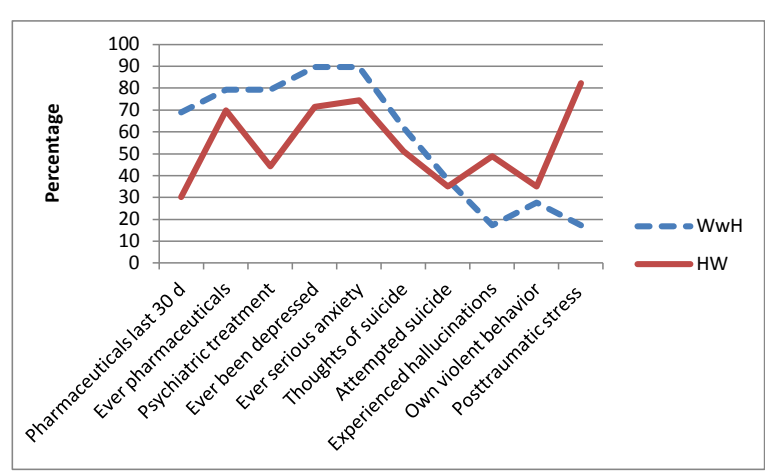

Figure 2: Percentages of self-reported psychological problems, for two groups of women exposed to male violence $(\mathrm{WwH}: \mathrm{n}=29 ; \mathrm{HW}: \mathrm{n}=43)$.

symptoms of hyperarousal, avoidance, and intrusion as more common among the HW compared to the WwH.

\section{SSP}

Results from the SSP presented in table 4 and figure 3, show that the overall scale score means for all women were outside the range of $1 \mathrm{SD}$ around norm mean $(\mathrm{T}=45-55)$ regarding subscales measuring somatic anxiety, stress susceptibility, embitterment, irritability, mistrust and verbal aggression. All HW but one reported being exposed to violence from one or more men, therefore the results from SSP are presented for the whole group that completed the questionnaire, $\mathrm{N}=72$. Significant differences were found between all $\mathrm{WwH}$ and all $\mathrm{HW}$ in variables measuring somatic anxiety, detachment, embitterment, mistrust, verbal and physical aggression, though both groups reported scores above norm mean for subscales of stress susceptibility and embitterment.

\section{IES-R measures}

Correlations between IES-R measures and SSP are presented in table 5. IES-R scales correlated significantly for the HW group with all clusters of SSP-scales except for the Introversion - Extraversion scales. For the $\mathrm{WwH}$ there were only two significant correlations obtained (Table 5).

\section{Other aspects of psychological health}

Results of the Addiction Severity Index used to question the women about mental problems during lifetime, are presented in Table 6. Notable is the difference between the two groups of women regarding psychiatric treatment where $74 \%$ of the $\mathrm{WwH}$ and $46 \%$ of the HW ( $p=0.01$ ) ever received treatment for their problems; and, ever had hallucinations (WwH 20\% and HW 48\%; $p=0.02$ ). Despite that, it was more common that the HW had disability pension due to psychiatric disorders compared to the $\mathrm{WwH}(p=0.033)$. Far more common for the HW were symptoms of PTSD (65\%) compared to the WwH (17\%) (RR $3,78 ; p<0.0001)$ see also Figure 2.

\section{Discussion}

Most women included in this study, both the WwH (29 of 35) and the HW (43 of 44), reported that they were subjected to male violence at some time during their lives. It is a very troubling result, even if it is not applicable to the whole population of women with substance dependence disorder. The results therefore should be interpreted with great caution. The women also had substantial problems with both psychological and physical health. The HW had, not surprisingly, more serious problems, despite the fact that they had been offered and/ or participated in substance abuse treatment. The $\mathrm{WwH}$ who were in treatment when the study was conducted, however, had better physical health, remained, in many cases, in the labour market, and in most cases also had custody of minor children, when compared with the HW. In recent studies it has been shown that homeless women were almost 21 times more likely to have been hospitalized for mental disorders, compared with women in the general population; and about six times more likely to have been hospitalized for injuries or infectious diseases [12-14].

Both groups also had experienced violence in childhood, and parental alcohol abuse and/or mental health problems. There is evidence that both individual risk, especially alcohol and/or drug use, and environmental factors in terms of family psychosocial characteristics, are influencing criminal behaviour and mortality in youth [36]. With this knowledge it is important to break the generational transmission of violence, drug abuse, and mental illness for women in treatment today [37].

In this study a number of personality traits significantly differed from norm population scores. Common comorbidity with substance dependence is antisocial personality disorder [38], conduct disorder

\begin{tabular}{|c|c|c|c|c|c|}
\hline \multirow[b]{2}{*}{ Exposed } & \multicolumn{2}{|c|}{$\mathrm{WwH}$} & \multicolumn{2}{|r|}{$\mathrm{HW}$} & \multirow[t]{2}{*}{$p$} \\
\hline & 29 & (83), $n=35$ & 43 & (98), $n=44$ & \\
\hline Current partner & 3 & $(10)$ & 14 & (33) & 0.046 \\
\hline Former partner & 23 & (79) & 40 & (93) & $n s$ \\
\hline Male acquaintance & 2 & (7) & 17 & (40) & 0.002 \\
\hline Person in authorities & 2 & (7) & 10 & (23) & $n s$ \\
\hline Father or male relative & 10 & (34) & 12 & (28) & ns \\
\hline
\end{tabular}

Table 2: Number (\%) of women being exposed to male violence, $\mathrm{WwH}(\mathrm{n}=29)$ and $\mathrm{HW}(\mathrm{n}=43)$. Results of Chi-square, Fisher's exact test, between $\mathrm{WwH}$ and HW, significant level

\begin{tabular}{|l|l|l|l|l|l|l|}
\hline \multicolumn{7}{|c|}{ Mean (SD) } \\
\hline & WwH & $W w H \geq 33 p$ & $H W$ & $H W \geq 33 p$ & $p$ \\
\hline & $n=29$ & $n=5$ & $n=43$ & $n=28$ & \\
\hline IES-R full score & $19.9(16.1)$ & $46.0(5.7)$ & $40.8(20.0)$ & $52.5(13.1)$ & $<.0001$ \\
\hline \multicolumn{7}{|c|}{ Mean (SD) Subscales } \\
\hline Intrusion & $1.0(0.8)$ & $2.2(0.3)$ & $1.9(1.1)$ & $2.5(0.9)$ & $<.001$ \\
\hline Avoidance & $1.0(0.9)$ & $2.1((0.5)$ & $1.9(0.9)$ & $2.4(0.7)$ & $<.0001$ \\
\hline Hyper arousal & $0.6(0.8)$ & $2.0(0.1)$ & $1.8(1.1)$ & $2.3(0.9)$ & $<.0001$ \\
\hline
\end{tabular}

Table 3: Mean scores and (SD) for two groups of women exposed to male violence (WwH: $n=29 ; \mathrm{HW}: \mathrm{n}=43$ ) in IES-R full scale (max $88 \mathrm{p}$ ) and the subscales Intrusion, Avoidance and Hyperarousal (each max $4 \mathrm{p}$ ). Results of Mann-Whitney's test between $\mathrm{WwH}$ and $\mathrm{HW}$, and significance level, as well as means and (SD) in the respective scales also for the women in the two groups $\geq 33(n=5$; and $n=28)$.

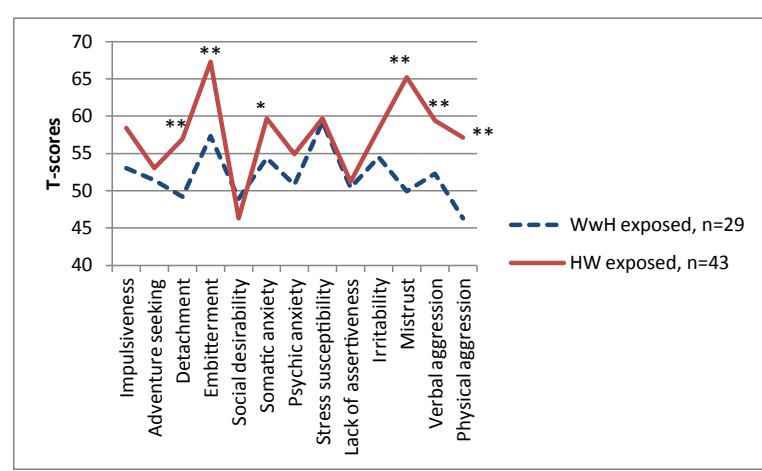

Figure 3: Mean T-scores in self-rated personality (SSP) scales for two groups of women exposed to male violence ( $\mathrm{WwH}: \mathrm{n}=29$; HW: $n=43)$, where norm mean $\mathrm{T}=50, \mathrm{SD}=10$. 


\begin{tabular}{|c|c|c|c|}
\hline & $\begin{array}{c}W w H \\
n=29\end{array}$ & $\underset{n=43}{H W}$ & $p$ \\
\hline \multicolumn{4}{|c|}{ Introversion-Extraversion scales } \\
\hline Impulsiveness & $53,0(11,6)$ & $58.4(13.6)$ & ns \\
\hline Adventure seeking & $51,4(10,5)$ & $53.0(12.4)$ & ns \\
\hline Detachment & $49,2(6,5)$ & $56,9(10,0)$ & $<.001$ \\
\hline \multicolumn{4}{|c|}{ Conformity - Nonconformity scales } \\
\hline Embitterment & $57,3(8,9)$ & $67,3(13,0)$ & $<.001$ \\
\hline Social desirability & $48,9(10.0)$ & $46.3(11.3)$ & ns \\
\hline \multicolumn{4}{|c|}{ Anxiety scales } \\
\hline Somatic anxiety & $54,4(8,1)$ & $59.7(11.8)$ & .047 \\
\hline Psychic anxiety & $50,8(8,8)$ & $54.9(10.8)$ & ns \\
\hline Stress susceptibility & $59,2(12,2)$ & $59.7(12.4)$ & ns \\
\hline Lack of assertiveness & $50,4(8,4)$ & $51.2(11.4)$ & ns \\
\hline \multicolumn{4}{|c|}{ Aggression scales } \\
\hline Irritability & $54,5(12,3)$ & $58.3(12.9)$ & ns \\
\hline Mistrust & $49,9(10,0)$ & $65.2(12.6)$ & $<.0001$ \\
\hline Verbal aggression & $52,3(7,1)$ & $59.4(11.1)$ & $<.003$ \\
\hline Physical aggression & $46,3(6,1)$ & $57.1(13.3)$ & $<.0001$ \\
\hline
\end{tabular}

Table 4: Mean T-scores and (SD) in self-rated personality scales (SSP) for two groups of women exposed to male violence $(\mathrm{WwH}: \mathrm{n}=29 ; \mathrm{WH}: \mathrm{n}=43)$ in self-rated personality traits (SSP). Results of Mann-Whitney's test and significance level

\begin{tabular}{|c|c|c|c|c|c|}
\hline & Full IES-R & Avoidance & Intrusion & \multicolumn{2}{|c|}{ Hyperarousal } \\
\hline & HW & HW & WwH & WwH & HW \\
\hline \multicolumn{6}{|c|}{ Introversion - Extraversion scales } \\
\hline Impulsiveness & & & & $0.96^{\star \star}$ & \\
\hline \multicolumn{6}{|c|}{ Conformity - Nonconformity scales } \\
\hline Embitterment & & $0.51^{* *}$ & & & \\
\hline \multicolumn{6}{|c|}{ Anxiety scales } \\
\hline Somatic anxiety & $0.43^{*}$ & & & & $0.51^{\star *}$ \\
\hline Psychic anxiety & & & & & $0.41^{*}$ \\
\hline \multicolumn{6}{|c|}{ Aggression scales } \\
\hline Irritability & & $0.50^{* *}$ & & & \\
\hline Mistrust & & $0.53^{\star \star}$ & & & \\
\hline $\begin{array}{l}\text { Physical } \\
\text { aggression }\end{array}$ & & & $0.97^{* *}$ & & \\
\hline
\end{tabular}

Table 5: Significant correlations between personality scale (SSP) scores and IES-R full scale and subscales Intrusion, Avoidance, Hyperarousal for two groups of women displaying a cut-off IES-R full scale point of $\geq 33(\mathrm{WwH}: n=5 ; \mathrm{HW}: \mathrm{n}=28)$

and borderline [39]. Both WwH and HW reported problems regarding stress susceptibility and feeling not being able to influence their situation (embitterment), signalling the need for enhanced coping methods in everyday life. Specific personality traits are indicators of increased risk of relapse in addiction [40]. Being victimized during early life could influence the development of personality traits [37]. A large proportion of the women in this study had experienced during their childhood violence from the father or another male relative or had witnessed violence between adults. One can therefore hypothesize that this has affected their personal development and that the large deviations from the normal population have emerged as a result of a major dysfunction in their ability tomanage and regulate stress and anxiety $[37,41]$.Therefore it should be of importance to help to improve coping strategies for reducing stress-induced mental ill-health [2]. To name and address questions related to earlier traumas, such as experienced violence, might offer possibility for the women to process their experiences in order to find more constructive coping methods than substance abuse, and thereby creating a better environment for their children's mental and physical health development [42].

When limited resources are available for mental health treatment it is plausible from one vantage point that the substantial needs of the HW be prioritized, thereby restricting the treatment efforts to the $\mathrm{WwH}$. However, such a vantage point runs the risk of limiting the much needed treatment efforts of the $\mathrm{WwH}$, for whom, one can assume, there are important opportunities to influence the effects of past trauma experiences and current and future substance abuse [2]. From a public mental health promotion perspective the preventionand early intervention efforts would be important not only for the women themselves but also for their children and the society in general.

The information that $91 \%$ of the women, who voluntarily participated in this study, had experienced male violence and not received any help for the consequences of this is alarming. Alcohol and substance abuse treatment must take into account that individuals, in addition to their addiction problem often have other related problems such as early life experiences that interact with their addiction problem. In Sweden the addiction treatment today rests on the ground of evidence improved methods. However, Sweden is still, to a certain extent, lacking a holistic approach and appropriate interventions to reduce further consequences of substance abuse, such as renewed traumas in terms of violence, exclusion from the labor market, loss of familial and social networks, and lost custody over their children. Treatment programs proved to be effective is family therapy and community reinforcement approach [43]. For those children who are now growing up in families, full or part time, where parents suffer from substance abuse, support structures are needed for the prevention of future mental and physical illness patterns [44].

There are some limitations of this study to be considered, the main one being the small sample. The results must be interpreted cautiously, as we may have accidentally examined a particular subgroup. However, the results can be seen as an important illustration of women subjected to male violence and the severity of the consequences for these women and their children, if remained untreated. We used standardized questionnaires with norm scores from a normal health population of women. Therefore we can conclude that, despite the limited number of women, the group of $\mathrm{WwH}$ and of $\mathrm{HW}$ were found to be very sensitive to stress and to internalizing a sense of not being able to influence their situation.

In substance abuse treatment settings in the Swedish cultural context the most focused efforts are on addressing alcohol dependence itself. However, earlier studies in women with dependence problems

\begin{tabular}{|l|c|c|c|}
\hline & $\begin{array}{c}\text { WwH } \\
\text { violence }\end{array}$ & $\begin{array}{c}\text { HW } \\
\text { violence }\end{array}$ & \\
\hline & $\mathrm{n}(\%)$ & $\mathrm{n}(\%)$ & $p$ \\
\hline Ever received psychiatric treatment & $26(79)$ & $19(44)$ & 0.004 \\
\hline Disability pension due to psychiatric disorders & $3(10)$ & $13(31)$ & 0.048 \\
\hline $\begin{array}{l}\text { Pharmaceuticals for psychiatric problems last } \\
\text { 30 d }\end{array}$ & $20(69)$ & $13(30)$ & 0.002 \\
\hline Ever pharmaceuticals for psychiatric problems & $23(79)$ & $30(70)$ & $n s$ \\
\hline Ever experienced serious anxiety & $26(90)$ & $32(74)$ & $n s$ \\
\hline Ever had thoughts of suicide & $18(62)$ & $22(51)$ & $n s$ \\
\hline Have been depressed & $26(90)$ & $30(71)$ & $n s$ \\
\hline $\begin{array}{l}\text { Have had problems with own violent } \\
\text { behaviours }\end{array}$ & $8(28)$ & $15(35)$ & $n s$ \\
\hline Have attempted suicide & $11(38)$ & $15(35)$ & $n s$ \\
\hline Ever had hallucinations & $5(17)$ & $21(49)$ & 0.007 \\
\hline $\begin{array}{l}\text { Posttraumatic stress symptoms exposed } \\
\text { to male violence }\end{array}$ & $5(17)$ & $28(65)$ & .000 \\
\hline
\end{tabular}

Table 6: Number and (percentage) of women that reported mental health problems in two groups of women exposed to male violence (WwH: $n=29$; HW: $n=43$ ). Results of Chi-square (Fisher's exact test), and significance level 
Citation: Birath CS, Beijer U, DeMarinis V, af Klinteberg B (2013) Women with Substance Abuse Problems Exposed to Men's Violence - A Public Mental Health Challenge. J Addict Res Ther 4: 149. doi:10.4172/2155-6105.1000149

have shown that other factors in life seem to be of great importance for the women to process during the treatment period $[26,27]$. To prevent or mitigate psychiatric problems are important factors for the women still having custody over their children [37].

\section{Conclusions}

The study indicated that women with substance dependence and with experience of male violence have major problems with both their psychological and physical health. Particularly vulnerable are the HW. Past experiences of violence that have not been processed can further aggravate current health, which is why we suggest that questions about experienced violence should be included in the treatment process in order to provide appropriate treatment interventions. For the $\mathrm{WwH}$, this may mean preventing serious consequences for both their housing situation and for their health. Further research is needed to elucidate prevention and treatment possibilities for women with substance abuse problems exposed to men's violence.

\section{Acknowledgments}

This study was supported by a research grant from the Crime Victim Compensation and Support Authority (Dnr 03663/2009 to Britt af Klinteberg). We are grateful to all those women who participated in the study, sharing their thoughts, feelings, experiences and behaviours.

\section{References}

1. The National Board of Health and Welfare (2011) Missbruket, Kunskapen, Vården. (SOU 2011:6) Missbruksutredningens forskarbilaga [The substance abuse, knowledge, care: Addictions Survey Research Appendix.] Offentliga förlaget, Stockholm.

2. Kalra G, Christodoulou G, Jenkins R, Tsipas V, Christodoulou N, et al. (2012) Mental health promotion: guidance and strategies. Eur Psychiatry 27: 81-86.

3. Romelsjö A (2007) Treatment of alcohol and drug abuse in drug treatment centers. How is the outcome for patients?. Lakartidningen 104: 1050-1055

4. Neale J (2008) Homelessness, drug use and hepatitis C: a complex problem explored within the context of social exclusion. Int J Drug Policy 19: 429-435.

5. World Health Organization (2004) Global Status Report on Alcohol 2004. World Health Organization, Department of Mental Health and Substance Abuse, Geneva.

6. Hallman J, von Knorring L, Edman G, Oreland L (1991) Personality traits and platelet monoamine oxidase activity in alcoholic women. Addict Behav 16: 533541.

7. Diem P, Deplazes M, Fajfr R, Bearth A, Müller B, et al. (2003) Effects of alcohol consumption on mortality in patients with Type 2 diabetes mellitus. Diabetologia 46: $1581-1585$

8. Neale J (2008) Homelessness amongst drug users: A double jeopardy explored. Int J drug Policy 192: 353-369.

9. Johnson G, Chamberlain C (2008) Homelessness and Substance Abuse: Which Comes First? Australian Social Work 64: 342-356

10. The National Board of Health and Welfare (2006) Homeless in Sweden 2005 Socialstyrelsen, Stockholm.

11. The National Board of Health and Welfare (2011) Homelessness in Sweden 2011. Socialstyrelsen, Stockholm.

12. Beijer U, Wolf A, Fazel S (2012) Prevalence of tuberculosis, hepatitis C virus, and HIV in homeless people: a systematic review and meta-analysis. Lancet Infect Dis 12: 859-870.

13. Beijer U, Andréasson S (2010) Gender, hospitalization and mental disorders among homeless people compared with the general population in Stockholm. Eur J Public Health 20: 511-516.

14. Beijer U, Andréasson S (2009) Physical diseases among homeless people: gender differences and comparisons with the general population. Scand $\mathrm{J}$ Public Health 37: 93-100.
15. Birath CS, DeMarinis V Stenbacka M af Klinteberg B (2011) Women with alcohol problems: the possible significance of personality clustering for treatment planning. Drug Alcohol Rev 30: 207-215.

16. Gros DF, Milanak ME, Brady KT, Back SE (2013) Frequency and severity of comorbid mood and anxiety disorders in prescription opioid dependence. Am J Addict 22: 261-265.

17. Berglund M, Ojehagen A (1998) The influence of alcohol drinking and alcoho use disorders on psychiatric disorders and suicidal behavior. Alcohol ClinExp Res 22: 333S-345S.

18. Bonomi AE, Anderson ML, Reid RJ, Rivara FP, Carrell D, et al. (2009) Medica and psychosocial diagnoses in women with a history of intimate partner violence. Arch Intern Med 169: 1692-1697.

19. Weiss D (2004) The Impact of Event Scale. In: Assessing psychological trauma and PTSD. John P. Wilson, Terence M. Keane (eds.), Guilford Press, New York.

20. Weinehall K (1997) Growing up in the proximity of violence: Teenagers' stories of violence in the home. Department of Education, Umea University, Sweden.

21. Lang S, af Klinteberg B, Alm PO (2002) Adult psychopathy and violent behavio in males with early neglect and abuse. ActaPsychiatrScandSuppl : 93-100.

22. The National Board of Health and Welfare (2007) National guidelines for persons with misuse and dependency problem.

23. Miller WR, Rollnick S (2002) Motivational Interviewing: Preparing People for change. (2d edn) Guilford Press, New York.

24. Marlatt GA, Relapse prevention: Theoretical rationale and overview of the model. Marlatt GA, Gordon J (edr.), Guilford Press, New York.

25. Marlatt GA, Gordon JR (1985) Relapse Prevention: Maintenance Strategies in the Treatment of Addictive Behaviors. Guilford Press, New York.

26. DeMarinis V, Scheffel-Birath C, Hansagi H (2009) Cultural analysis as a perspective for gender-informed alcohol treatment research in a Swedish context. Alcohol Alcohol 44: 615-619.

27. Birath CS, DeMarinis V, af Klinteberg B (2010) Moods and expectancies of female alcohol drinking--an exploratory study. Scand J Caring Sci 24: 472-481.

28. Andreasson S, Allebeck P (2005) Alkohol och hälsa - en kunskapsöversikt om alkoholens positiva och negativa effekter på vår hälsa [Alcohol and Health effects of alcohol on our health.] Folkhälsoinstitutet, Taberg Media Group AB Stockholm.

29. Finne E (2003)Statistik över socialtjänstens kontakter med missbrukare hemlösa och psykiskt störda i Stockholm år 2001. [Statistics of social services contact with substance misusers, homeless, and people with mental disorders in Stockholm 2001.] FOU-rapport. Socialtjänstförvaltningen, FOU-enheten Stockholm.

30. Creamer M, Bell R, Failla S (2003) Psychometric properties of the Impact of Event Scale - Revised. Behav Res Ther 41: 1489-1496.

31. Griffing S, Lewis CS, Chu M, Sage RE, Madry L, et al. (2006) Exposure to interpersonal violence as a predictor of PTSD symptomatology in domestic violence survivors. J Interpers Violence 21: 936-954.

32. Gustavsson JP, Bergman H, Edman G, Ekselius L, von Knorring L, et al (2000) Swedish universities Scales of Personality (SSP): construction, internal consistency and normative data. Acta Psychiatr Scand 102: 217-225.

33. World Health Organization, Questionnaire, in WHO Multi-country Study on Women's Health and Life Experiences, Department of Gender Women and Health, Editor 2003, World Health Organisation: Geneva.

34. Mc Lellan AT (1985) Guide to the addiction severity index: background, administration, and field testing results. DHHS publication, Washington.

35. Andreasson S (1999) ASI: En strukturerad intervjumetod för bedömning av alcohol- och narkotikarelaterade problem [ASI: A semi-structured interview designed to address seven potential problem areas in substance-abusing patient]. Centrum för utvärdering av social arbete (CUS): Spånga.

36. af Klinteberg B, Almquist Y, Beijer U, Rydelius PA (2011) Family psychosocia characteristics influencing criminal behaviour and mortality - possible mediating factors: A longitudinal study of male and female subjects in the Stockholm Birth Cohort. BMC Public Health 11: 756-770.

37. Daud A, af Klinteberg B, Rydelius PA (2008) Resilience and vulnerability among refugee children of traumatized and non-traumatized parents. Child Adolesc Psychiatry Ment Health 2: 7. 
Citation: Birath CS, Beijer U, DeMarinis V, af Klinteberg B (2013) Women with Substance Abuse Problems Exposed to Men's Violence - A Public Mental Health Challenge. J Addict Res Ther 4: 149. doi:10.4172/2155-6105.1000149

Page 7 of 7

38. Fridell M, Hesse M, Johnson E (2006) High prognostic specificity of antisocial personality disorder in patients with drug dependence: results from a five-year follow-up. Am J Addict 15: 227-232.

39. Jansson I, Hesse M, Fridell M (2009) Influence of personality disorder features on social functioning in substance-abusing women five years after compulsive residential treatment. European addiction research 15: 25-31.

40. Greenfield SF, Brooks AJ, Gordon SM, Green CA, Kropp F, et al. (2007) Substance abuse treatment entry, retention, and outcome in women: a review of the literature. Drug Alcohol Depend 86: 1-21.

41. Ahlström S, Bloomfield K, Knibbe R (2001) Gender Differences in Drinking Patterns in Nine European Countries: Descriptive Findings. Subst Abus 22:
$69-85$

42. Muhsen K, Garty-Sandalon N, Gross R, Green MS (2010) Psychological distress is independently associated with physical inactivity in Israeli adults. Prev Med 50: 118-122.

43. Meis LA, Griffin JM, Greer N, Jensen AC, Macdonald R, et al. (2013) Couple and family involvement in adult mental health treatment: a systematic review. Clin Psychol Rev 33: 275-286.

44. Spatz Widom C (1997) Child abuse, neglect, and witnessing violence. In Handbook of antisocial behavior. Stoff DM, Breiling J, Maser JD (Eds.), Wiley, New York, USA.
Citation: Birath CS, Beijer U, DeMarinis V, af Klinteberg B (2013) Women with Substance Abuse Problems Exposed to Men's Violence - A Public Mental Health Challenge. J Addict Res Ther 4: 149. doi:10.4172/2155-6105.1000149
Submit your next manuscript and get advantages of OMICS Group submissions

Unique features:

- User friendly/feasible website-translation of your paper to 50 world's leading languages

- Audio Version of published paper

Digital articles to share and explore

Special features:

250 Open Access Journals

20,000 editorial team

21 days rapid review proces

Quality and quick editorial, review and publication processing

Indexing at PubMed (partial), Scopus, DOAJ, EBSCO, Index Copernicus and Google Scholar etc Sharing Option: Social Networking Enabled

Authors, Reviewers and Editors rewarded with online Scientific Credits

Better discount for your subsequent articles

Submit your manuscript at: http://www.omicsonline.org/submission 